\title{
Антибіотикоасоційована діарея: роль пробіотиків у лікуванні та профілактиці
}

\author{
І.М. Скрипник, Н.П. Приходько \\ Українська медична стоматологічна академія, Полтава, Україна
}

Анотація. Антибактеріальні препарати, як і будь-які лікарські засоби, мають певні побічні ефекти, зокрема одним з них $\epsilon$ діарея, спричинена їхнім застосуванням. У статті розглянуті основні причини розвитку антибіотикоасоційованої діареї, форми захворювання, особливості діагностики та етіотропного лікування. На підставі аналізу публікацій вітчизняних і зарубіжних дослідників представлені дані щодо застосування пробіотиків з метою профілактики та лікування антибіотикоасоційованої діареї. Розглянуті можливості використання пробіотиків, зокрема Bifidobacterium lactis BB-12 ${ }^{\circledR}$ та Lactobacillus acidophilus $L A-5^{\circledR}$ для профілактики ускладнень антигелікобактерної інфекції, вплив їх на глікемічний контроль та ліпідний профіль пацієнтів.

Ключові слова: антибіотикоасоційована діарея, пробіотики, Bifidobacterium lactis BB-12 ${ }^{\circledR}$, Lactobacillus acidophilus $L A-5^{\oplus}$.

Широке застосування антибактеріальних препаратів дозволило людству вирішити ряд проблем інфекційного походження, але водночас це спонукало до появи нових ятрогенних захворювань, зокрема антибіотикоасоційованої діареї (ААД).

ААД - це $\geq 3$ епізодів неоформлених випорожнень протягом $\geq 2$ послідовних днів, які виникають на фоні або протягом 2 міс після застосування антибактеріальних засобів.

Частота виникнення ААД у популяції коливається в межах 5-35\% випадків і залежить від віку пацієнта та виду антибіотиків [1]. ААД вважають переважно внутрішньолікарняною патологією (20$25 \%)$, яка у деяких випадках може досягати $60 \%$ [2]. Проте останнім часом спостерігається тенденція до зростання частоти цього ускладнення серед амбулаторних пацієнтів [3-5].

Застосування будь-яких антибіотиків може викликати діарею, особливо тих, що впливають на анаероби. Проте частіше прийом амінопеніцилінів, цефалоспоринів II і III поколінь, лінкоміцину та кліндаміцину пов'язаний з високим ризиком розвитку ААД [6-8].

Важливо відзначити, що парентеральний шлях введення антибіотика не має переваги над пероральним шляхом як профілактики ААД. При парентеральному введенні антибіотик впливає на мікробіоту опосередковано - через слину, жовч, секрет кишечнику [9, 10].

Факторами ризику розвитку ААД $\epsilon$ : призначення кількох антибіотиків одночасно або у високих дозах, нераціональне їх застосування; вік пацієнтів <5 років та > 65 років; наявність супутньої патології, зокрема цукрового діабету, запальних захворювань кишечнику; одночасний прийом інгібіторів протонної помпи; тривала госпіталізація; оперативні втручання та інвазивні процедури [11, 12].

\section{Варіанти клінічного перебігу}

3 практичної точки зору слід виділяти дві форми ААД — неінфекційну та інфекційну.

у більшості випадків діарея при застосуванні антибіотиків не має інфекційного походження (ідіопатична ААД), зумовлена прямим або опосередкованим впливом антибіотиків на кишечник та інші відділи травного тракту. Зокрема посилення моторики кишечнику власне антибактеріальним препаратом викликає гіперкінетичну діарею; неповне всмоктування антибіотиків із просвіту кишечнику - осмотичну діарею; вплив на кишковий кровообіг; токсичний вплив на структуру кишкового епітелію; порушення складу кишкової мікрофлори, в результаті якого розвивається надмірна декон'югація жовчних кислот, що надходять у просвіт товстої кишки, та синтез хлоридів і води - секреторну діарею [13-15].

Особливістю клінічної картини ідіопатичної ААД $\epsilon$ невиражене послаблення випорожнень, без патологічних домішок у калі, що не супроводжується підвищенням температури тіла, зростанням рівня лейкоцитів у крові, за відсутності запальних змін слизової оболонки кишечнику.
Частота інфекційної ААД становить 20-25\% усіх випадків. її збудниками $\in$ Clostridium difficile (C. difficile), Clostridium perfringens, Salmonella spp., Staphylococcus aureus, Klebsiella oxytoca, Candida, які здатні колонізувати кишечник на фоні порушеного кількісного та якісного складу мікробіому [16].

За останні три десятиліття частота і тяжкість інфекційної ААД зросли у багатьох країнах світу. Це пов'язано з появою нових високовірулентних штамів C. difficile BI/NAP1/027, 106 та 018, а також із широким застосуванням інгібіторів протонної помпи та статинів [17].

C. difficile - облігатно-анаеробна грампозитивна спороутворююча бактерія, що має природну стійкість до більшості антибіотиків. C. difficile у просвіті кишечнику продукує токсини A і B, з якими пов'язують основні прояви інфекції. Токсин А зв'язується зі специфічними рецепторами на апікальній поверхні епітеліальних клітин, викликає зміни цитоскелета і пошкодження міжклітинних з'єднань. Це спричиняє проникнення токсину В усередину клітини, його приєднання до базальної мембрани, підвищення проникності судин, синтез нейропептидів і прозапальних цитокінів, апоптоз епітеліальних клітин, утворення псевдомембран, гіперсекреції води і електролітів [18].

\section{Клінічна симптоматика та діагностика}

Клінічними проявами псевдомембранозного коліту (ПМК), спричиненого інфекцією C. difficile, $\epsilon$ діарея до 20-30 разів на добу з домішками слизу й крові, що супроводжується вираженим абдомінальним болем та синдромом системної запальної відповіді. Перебіг ПМК тяжкий, часто торпідний і може ускладнюватися дегідратацією та електролітними порушеннями, гіповолемічним шоком, токсичним мегаколоном, гіпоальбумінемією і набряками, у дуже тяжких випадках - кишковою кровотечею, перфорацією кишечнику з розвитком перитоніту [19]. При ПМК колоноскопія дозволяє виявити характерні макроскопічні зміни товстої кишки: псевдомембрани з некротизованого епітелію з фібрином, при легких формах - розвиток катаральних змін у вигляді повнокрів'я і набряку слизової оболонки. Найпоширенішими методами лабораторної діагностики інфекції C. difficile $\epsilon$ імуноферментний аналіз, ПЛР-тест і цитотоксичний тест із використанням специфічних антисироваток у реакції нейтралізації. Золотим стандартом діагностики інфекції C. difficile $є$ цитотоксичний тест для виявлення токсину В $[8,20]$.

\section{Принципи лікування}

При появі у пацієнта симптомів ААД перш за все необхідно відмінити антибактеріальний препарат, який викликав діарею. у більшості випадків ідіопатичної ААД та у $1 \frac{1}{3}$ пацієнтів із нетяжкими формами інфекції C. difficile цього достатньо для нормалізації стану пацієнта. За відсутності позитивної динаміки від відміни антибіотиків призначають етіотропну терапію, спрямовану на елімінацію інфекційного збудника, що викликав діарею. 
При легкому чи середньому ступені тяжкості вперше виявленої C. difficile-інфекції призначають метронідазол у дозі 500 мг 3 рази на добу протягом 10 днів, в інших випадках - ванкоміцин 125 мг 4 рази на добу 10 днів перорально або фідаксоміцин 200 мг 2 рази на добу 10 днів перорально. Додатково у комплексі лікування застосовують сорбенти, проводять корекцію водно-електролітного балансу. Пацієнтам із C. difficile-інфекцією слід уникати застосування антидіарейних препаратів, опіатів [21].

Пробіотики (Lactobacillus spp., Bifidobacterium spp., Saccharomyces boulardi) рекомендують для лікування у разі ідіопатичної ААД та нетяжких форм C. difficile-інфекції, особливо при рецидивуючому перебігу захворювання. Механізм дії пробіотиків полягає в наявності антагоністичної активності щодо C. difficile шляхом інгібування адгезії збудника, модуляції імунної відповіді макроорганізму і стимуляції синтезу специфічного антитоксину імуноглобуліну А. Застосування пробіотиків з антибактеріальними препаратами у пацієнтів із факторами ризику розвитку інфекцій, викликаних C. difficile, знижує ризик розвитку ААД та ПМК [22].

Тяжкість і можливі наслідки ААД зумовлюють розроблення засобів профілактики цієї патології. Перш за все це - раціональна антибіотикотерапія, дотримання правил гігієни для запобігання екзогенній трансмісії бактерій або спор C. difficile, одночасне застосування пробіотиків з основним курсом антибіотиків [23].

У жовтні 2013 р. Міжнародна наукова асоціація пробіотиків та пребіотиків (International Scientific Association for Probiotics and Prebiotics - ISAPP) скликала експертну комісію з метою обговорення пробіотиків. Після обговорення гайдлайнів Продовольчої і сільськогосподарської організації Об'єднаних Націй/Всесвітньої організації охорони здоров'я (Food and Agriculture Organization of the United Nations/World Health Organization — FAO/WHO) дано визначення пробіотикам, як «живим мікроорганізмам, які при введенні їх у достатній кількості приносять користь для здоров'я господаря» $[23,24]$.

Ефект пробіотиків пояснюється тим, що мікроорганізми, які входять до їх складу, заміщають функції власної нормальної кишкової мікрофлори [25-27]:

- підтримку стабільності мікробіоценозу та запобігання колонізації кишечнику патогенними і умовно-патогенними мікроорганізмами;

- участь у процесах утилізації білків, ліпідів, високомолекулярних вуглеводів, нуклеїнових кислот, клітковини, синтезі вітамінів групи B;

- участь в електролітному обміні, регуляції метаболізму жовчних кислот, холестерину (ХC);

- участь у детоксикації екзогенних та ендогенних субстратів нормальна флора виступає в ролі «природного сорбенту» шляхом мікробної трансформації токсичних речовин;

- синтез речовин з антибактеріальною активністю;

- стимуляцію перистальтики кишечнику;

- поліпшення засвоєння солей кальцію і вітаміну D;

- підвищення резистентності та імунної реактивності організму: стимуляція лімфоїдного апарату, синтезу імуноглобулінів, підвищення активності лізоциму і зниження проникності судинних тканинних бар'єрів для токсичних продуктів патогенних мікроорганізмів;

- антиканцерогенну дію - знищення атипових клітин організму в результаті активації імунних процесів.

До складу пробіотиків входять багато штамів нормальної кишкової мікрофлори, більшість з них належать до роду Lactobacillus та Bifidobacterium, одними з основних представників яких $\epsilon$ пробіотичні штами Bifidobacterium animalis subspecies lactis BB$12^{\circ}$ (B. lactis $B B-12^{\circ}$ ) та Lactobacillus acidophilus $L A-5^{\circ}$ (L. acidophilus $L A-5^{\circ}$.

B. lactis $B B-12^{\circ}$ міститься в природній біоплівці кишечнику здорових людей і забезпечує стійкість до його колонізації патогенними мікроорганізмами, пригнічуючи активність Bacillus cereus, C. difficile, Clostridium perfringens типу A, Escherichia coli, Enterococcus faecalis, Listeria monocytogenes, Pseudomonas aeruginosa, Salmonella typhimurium, Salmonella typhi, Shigella flexneri, Shigella sonnei, Candida albicans.
При цьому за своєю антагоністичною активністю $B B-12^{\circ}$ значно перевищує інші подібні штами $[28,29]$.

Штам L. acidophilus $L A-5^{\circ}$ у процесі своєї життєдіяльності ферментує глюкозу, в результаті чого утворюються лактат, ацетат і перекис водню [30], які підтримують кислі значення рН у кишечнику, перешкоджаючи розвитку патогенної протеолітичної мікрофлори. Kрім того, L. acidophilus LA-5 ${ }^{\circ}$ виробляє бактеріоцини (ацидоцин CH5) з вираженим рівнем антибактеріальної активності. Їх дія реалізується за рахунок деградації пептидоглікану клітинної стінки, пригнічення синтезу білків, ДНК або РНК, індукції аутолізу патогенних або умовно-патогенних бактерій і грибів. Особливістю штаму $є$ резистентність до багатьох антибактеріальних препаратів, що дозволяє використовувати його одночасно з ними [31].

Крім вищезазначених властивостей, штам L. acidophilus $L A-5^{\circ}$ бере участь у синтезі >70\% вітамінів в організмі людини, процесах детоксикації, синтезі протизапальних факторів та визнаний активним антагоністом патогенного штаму Escherichia coli [32]. Біологічні ефекти цих штамів взаємно посилюються при комбінованому їх застосуванні, зокрема адгезія B. lactis BB-12 ${ }^{\circ}$ до слизової оболонки кишечнику зроста $\epsilon$ y $>2$ раза за наявності L. acidophilus $L A-5^{\circ}[33,34]$.

Доведений вплив B. lactis BB-12 $2^{\circ}$ та L. acidophilus $L A-5^{\circ}$ на імунологічний профіль людини - активацію фагоцитозу, синтез лізоциму, секреторного імуноглобуліну А і протизапальних цитокінів, зниження синтезу інтерлейкіну-6, -12 та імуноглобуліну E $[35,36]$ та сповільнення поступового зниження імунітету з віком [37].

Вітчизняні вчені вивчали вплив лакто- та біфідобактерій на інтерфероногенез та функціональну активність клітин фагоцитарної системи in vivo [38]. Встановлено їх активуючий вплив на продукцію, як «раннього», так i «пізнього» ендогенного інтерферону у плазмі крові мишей. Введення мишам штамів лакто- та біфідобактерій супроводжувалось активацією киснезалежної бактерицидності та поглинальної активності макрофагів черевної порожнини.

Доведений також вплив пробіотиків на моторику кишечнику та консистенцію випорожнень. Зв'язок між мікрофлорою та кишковою моторикою здійснюється за участю TLR-рецепторів, які відповідають за кишковий епітеліальний гомеостаз. Зокрема на експериментальних моделях встановлена значна затримка моторики шлунково-кишкового тракту у TLR4-мутантних мишей [39].

За участю 1248 пацієнтів проведене багатоцентрове подвійне сліпе рандомізоване плацебо-контрольоване дослідження [40] з метою оцінки впливу B. lactis BB-12 $2^{\circ}$ на частоту дефекацій та відчуття дискомфорту в животі протягом 4 тиж. Пацієнти були розподілені на три групи: 1-ша отримувала капсули з пробіотиком $B B-12^{\circ}$ у дозі

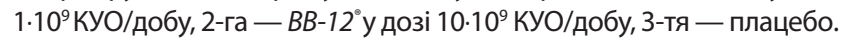
У ході дослідження встановлено суттєвий вплив прийому пробіотика на середню кількість дефекацій. При цьому частота дефекацій була достовірно вищою в групах застосування пробіотиків у цілому. Відмінностей між групами щодо відчуття абдомінального дискомфорту не встановлено, що може свідчити про хорошу переносимість пробіотика B. lactis BB-12 .

За даними S.-Ch. Li та співавторів (2019), встановлено перевагу комбінації штамів L. acidophilus та B. lactis як протизапальних чинників на культурі пухлинних клітин товстої кишки НТ-29 [41].

Численні експериментальні та клінічні дані показали позитивний ефект від застосування пробіотиків для профілактики ААД. Так, у метааналізі Y. Gong та співавторів (2015) за участю 3900 пацієнтів показано, що застосування пробіотиків знижувало частоту розвитку нудоти (7 та 11,9\%), діареї (6,3 та 14,7\%), болю в епігастрії (8,9 та 11,7\%), блювання (2,5 та 7,2\%) і шкірного висипу (3,8 та 11,5\%) [42]. Інша група дослідників провела аналіз 17 досліджень з бази PubMed, що включали 3631 особу [43]. Встановлено, що ААД була наявна у 8,0\% пацієнтів, які отримували пробіотичну терапію, і у $17,7 \%$, які отримували плацебо.

Широку популярність у медичному науковому середовищі отримали результати метааналізу 33 рандомізованих досліджень (6352 досліджених), який показав помірний протекторний ефект пробіотиків при ААД у педіатричній практиці [44]. Встановлено скорочення тривалості ААД при застосуванні пробіотиків у дозі $>5 \cdot 10^{9} \mathrm{KУO/добу} \mathrm{та} \mathrm{меншій} \mathrm{частоті} \mathrm{ААД} \mathrm{-} \mathrm{до} 8 \%$ у групі, які отри- 
мували високі дози пробіотиків, порівняно з 23\% - у контрольній групі.

Трикомпонентну ерадикаційну терапію, що включає інгібітор протонної помпи і два антибіотики, широко застосовують для лікування захворювань, асоційованих із Helicobacter pylori (H. pylori). Однак слід відзначити високу частоту небажаних явищ (до 30-40\%), що супроводжують їі [42]. Тому актуальним залишається питання пошуку методів підвищення ефективності та безпеки ерадикаційної терапії Н. pylori-інфекції.

У дослідженні E.J. Videlock та співавторів (2012) проаналізовано ризик ААД під час лікування Н. pylori-інфекції, який становив 0,37 проти 5, у тих, які не отримували пробіотики [45]. У метааналізі 13 досліджень із залученням >2300 пацієнтів встановили ефективність додаткового застосування пробіотиків на фоні антигелікобактерної терапії [46]. Частота загальних побічних ефектів, пов'язаних 3 антибіотиками, була достовірно нижчою у групі, які отримували пробіотики, порівняно з контрольною групою, про що свідчить показник загального ризику, який становив 0,71.

M. De Vrese та співавтори (2011) вивчали ефекти при вживанні йогурту, що містить комбінацію $L$. acidophilus $L A-5^{\circ}$ i $B$. lactis $B B-12^{\circ}$, на профілактику розвитку ААД у пацієнтів, які отримували антигелікобактерну терапію [47]. Встановлено нижчу частоту епізодів ААД та меншу тривалість діареї у групах пацієнтів, що отримували пробіотичну терапію.

Опубліковані результати метааналізу H.R. Fang та співавторів (2019), що базується на 5 дослідженнях із включенням 484 пацієнтів, в якому оцінювали ефективність лактобактерій на фоні трикомпонентної ерадикаційної терапії у дітей [48]. Об'єднаний відносний ризик (relative risk - RR) ерадикації у групі пробіотиків становив 1,19. Також встановлено, що при застосуванні великих доз лактобактерій ефективність ерадикації була вищою: $R R=1,36$ проти 1,08 при застосуванні низьких доз. На ефективність ерадикації впливала також тривалість курсу пробіотиків: $\mathrm{RR}=1,24$ при довготривалому застосуванні та 1,17 - при коротких курсах. Прийом лактобактерій на фоні ерадикаційної терапії значно зменшив частоту діареї $(\mathrm{RR}=0,30)$.

Пробіотичним препаратом, який доцільно призначати для лікування і профілактики ААД, $є$ Лінекс Форте, 1 капсула якого містить суміш пробіотиків: Lactobacillus acidophilus - не менше $1 \times 10^{9} \mathrm{KVO}$ (приблизно 25,74 мг), Bifidobacterium animalis subsp. lactis - не менше $1 \times 10^{9}$ KУО (приблизно 3,06 мг).

L. acidophilus $L A-5^{\circ}$ продукують молочну кислоту та перекис водню, конкурують із патогенними мікроорганізмами, покращують обмінні процеси, запобігають формуванню затяжних форм кишкових захворювань, стимулюють синтез імуноглобулінів та інтерферонів.

B. lactis BB-12 $2^{\circ}$ синтезують вітаміни групи $\mathrm{B}$, амінокислоти, пригнічують колонізацію патогенних мікроорганізмів, конкурують із патогенними бактеріями за поживні речовини.

Серед допоміжних речовин важливе значення має оригінальний запатентований інуліновий пребіотик Beneo Synergy - інулін, олігофруктоза (глюкоза + фруктоза + сахароза), що забезпечує харчування для корисних бактерій, стимулюючи зростання та розвиток лакто- та біфідобактерій.

Резистентність L. acidophilus i B. lactis до хлористоводневої кислоти і жовчі зумовлює високий ступінь виживаності цих штамів при проходженні через шлунок і дванадцятипалу кишку. Обидва штами молочнокислих бактерій можуть адсорбуватися на слизовій оболонці кишечнику та, подібно до інших мікроорганізмів травного тракту, поступово виводитися при перистальтиці й дефекації.

Лінекс Форте повною мірою відповідає усім вимогам до сучасних пробіотиків: вивченість (визначений за класом та штамами, має генетичний паспорт), життєздатність бактерій (резистентність до дії хлористоводневої кислоти, жовчі, ферментів шлунково-кишкового тракту), кожен штам L. acidophilus $L A-5^{\circ}$ і B. lactis BB-12 $2^{\circ}$ містить до $1 \cdot 10^{9} \mathrm{KУO} \mathrm{(згідно} \mathrm{з} \mathrm{вимогами} \mathrm{-} \mathrm{не} \mathrm{менше} 1 \cdot 10^{7} \mathrm{KУO}$ ) і доведена висока ефективність при застосуванні [49].

Лакто- та біфідобактерії потенціюють дію одне одного. 3береженню життєздатності бактерій впродовж тривалого часу сприяє процес ліофілізації [50].
Ефективність комбінації пробіотиків L. acidophilus $L A-5^{\circ}$ і $B$. lactis $B B-12^{\circ}$ на розвиток ААД вивчали S. Chatterjee та співавтори (2013) [51]. Після 14-денного лікування частота ААД у групі, яка отримувала пробіотики, була значно знижена - до 10,8\% порівняно з 15,6\% у групі плацебо. Тривалість діареї була значно меншою (2,32 дні) у групі, яка отримувала пробіотики, порівняно з групою плацебо (4,58 дня). Частота тяжкої діареї у групі плацебо становила $96 \%$ проти 31,6\% у групі, яка отримувала пробіотики. Ці результати показують, що мікробні компоненти Лінекс Форте ефективно зменшують тривалість та тяжкість ААД.

Вплив застосування пробіотиків у дітей віком 1-12 років на фоні призначення антибіотиків вивчали M.J. Fox та співавтори (2015) [52]. Діти отримували 2 рази в день по 100 г йогурту, що міс-

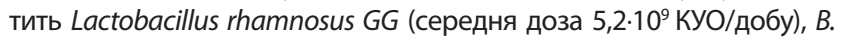

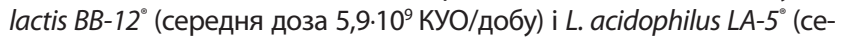
редня доза 8,3·10 KУО/добу) або йогурт без пробіотиків. У групі дітей, які отримували пробіотики, встановлено 1 випадок легкої діареї, тоді як у контрольній відзначали 21 випадок діареї. Крім того, небажані явища виникали майже у 4 рази рідше на тлі прийому пробіотиків (по 1 випадку дискомфорту в животі, блювання і головного болю) порівняно $з$ плацебо (6 випадків болю в животі, 4- зниження апетиту і 1 - нудоти), що свідчить про безпеку штамів, які входять до складу препарату Лінекс Форте

Пробіотичні штами препарату Лінекс Форте виявляють антагонізм до умовно-патогенних стафілококів, клебсієл та грибів, при цьому зберігаючи біосумісність із домінуючими представниками кишкового мікробіоценозу Escherichia, Bifidobacterium, Enterococcus. Задля захисту мікрофлори кишечнику від негативної дії антибіотиків і профілактики ААД прийом Лінекс Форте слід розпочинати з 1-го дня застосування антибіотиків по 1 капсулі на добу незалежно від віку пацієнта, дотримуючись інтервалу у 3 год між прийомом антибіотика і пробіотика. Дорослим і дітям віком >12 років при лікуванні діареї препарат призначають по 2-3 капсули на добу залежно від вираженості симптомів [50].

Чимало досліджень останніх років підтверджують важливий вплив кишкової мікробіоти не лише на роботу шлунково-кишкового тракту, а й на функціонування усіх органів і систем у цілому. Встановлені дані про взаємний вплив кишечнику і центральної нервової системи за участю автономної нервової системи, ентеральної нервової системи, гіпоталамо-гіпофізарно-адреналової осі та ендокринних клітин кишечнику [53].

Кишковий дисбіоз може супроводжуватися підвищенням тривожності, депресивною поведінкою, порушенням пам'яті, зниженням рівня ключових нейротрофічних факторів. В експерименті на мишах показано, що зміна нормального складу мікробіоти кишечнику може спричинити порушення поведінки та пригнічувати функції мозку, зумовити відхилення від норми у нейрохімічних показниках [54]. Доведений вплив пробіотиків на покращення пластичності гіпокампа, мітохондріальної функції мозку та зниження мікрогліальної активації [55]. У роботі С. Yang та співавторів (2017) доведено, що біфідобактерії кишечнику можуть забезпечити стійкість до хронічного стресу, а їх пероральний прийом сприяє полегшенню симптомів депресії [56].

Доведено, що певні штами лакто- та біфідобактерій ефективно сприяють зниженню рівня загального XС та ХС ліпопротеїдів низької щільності (ЛПНЩ). Так, L. Wang та співавтори (2018) опублікували результати метааналізу 32 рандомізованих клінічних досліджень за участю 1971 пацієнта, в якому оцінювали вплив пробіотичної терапії на рівень загального XС [57]. Результати показали, що порівняно $з$ контрольною групою рівень загального ХС у сироватці крові був значно знижений у групі, яка отримувала пробіотики. Встановлено також вплив певних штамів пробіотиків на суттєве зниження рівня загального XC, зокрема у групі пацієнтів, що отримували L. acidophilus $L A-5^{\circ}$ та B. lactis.

R. Мо та співавтори (2019) проаналізували 19 рандомізованих клінічних досліджень, що включали 967 учасників [58]. Прийом пробіотиків знижував рівень загального ХС і ХС ЛПНЩ порівняно 3 контролем на 0,25 та 0,17 ммоль/л відповідно. Значного впливу пробіотиків на рівень тригліцеридів та ХС ліпопротеїдів високої щільності не виявлено. 
Можливими механізмами гіполіпідемічного ефекту пробіотиків $\epsilon$ бактеріальна асиміляція в кишечнику і декон'югація солей жовчних кислот [59]. Поряд з цим встановлено, що коротколанцюгові жирні кислоти, які продукуються лактобактеріями, здатні пригнічувати синтез XС в печінці та його транспорт у плазму крові [60].

H.S. Ejtahed та співавтори (2011) оцінювали вплив йогурту, збагаченого пробіотиками $L$. acidophilus $L A-5^{\circ}$ і $B$. lactis $B B-12^{\circ}$ та звичайного йогурту на ліпідний профіль пацієнтів із цукровим діабетом [61]. Встановлено зниження рівня загального ХС на 4,54\% та ХС ЛПНЩ - на 7,45\% у групі, де застосовували пробіотичний йогурт, в основі якого - штами бактерій препарату Лінекс Форте , порівняно $з$ контрольною групою.

у роботі L.B. Tonucci та співавторів (2017) у пацієнтів із цукровим діабетом 2-го типу вивчали вплив комплексу пробіотиків $L$. acidophilus $L A-5^{\circ}$ і $B$. lactis $B B-12^{\circ}$ на рівень глікемії та ліпідний профіль, оксидативний стрес і вміст коротколанцюгових жирних кислот [62]. Через 6 тиж у пацієнтів, які отримували пробіотики, відзначали зниження рівня фруктозаміну (на 9,91 ммоль/л) і глікованого гемоглобіну (на 0,67\%) порівняно з показниками до початку прийому пробіотиків. Встановлена значуща різниця між групами щодо середніх значень рівня глікованого гемоглобіну (+0,31 у групі плацебо та $-0,65$ - у групі пробіотиків; $p=0,02)$, загального XC (+0,55 та -0,15 відповідно; $\mathrm{p}=0,04)$ і ХС ЛПНЩ (+0,36 та -0,20 відповідно; $p=0,03)$.

Вплив пробіотиків на кардіометаболічні параметри пацієнтів із цукровим діабетом 2-го типу вивчали Т. Косsis та співавтори (2020) на підставі аналізу 32 клінічних досліджень з баз MEDLINE, Embase та CENTRAL [63]. Результати показали значний вплив прийому пробіотиків на зниження загального XC, рівня тригліцеридів, С-реактивного протеїну, глікованого гемоглобіну, глюкози та інсуліну натще, а також на систолічний та діастолічний артеріальний тиск. Доповнення основної терапії пробіотиками підвищувало рівень XС ліпопротеїдів високої щільності, однак не мало значного впливу на індекс маси тіла або рівень ХС ЛПНЩ.

Таким чином, на сьогодні в багатьох метааналізах підтверджені позитивні ефекти пробіотиків в цілому та зокрема штамів B. lactis BB$12^{\circ}$ та L. acidophilus LA-5. Ц Ця комбінація показала себе ефективною щодо нормалізації функції кишечнику, лікування та профілактики діареї, в тому числі ААД. Прийом пробіотика сприяє кращій переносимості ерадикаційної терапії H. pylori та нижчій частоті небажаних явищ у разі їх виникнення. Синергізм штамів L. acidophilus $L A-5^{\circ}$ i $B$. lactis $B B-12^{\circ}$ покращує функціонування імунної системи, глікемічний контроль, ліпідний профіль, а також позитивно впливає на когнітивні властивості пацієнтів, зокрема з коморбідною патологією.

Лінекс Форте показаний для застосування у складі комплексного лікування дисбіозу кишечнику, для запобігання та лікування діареї, здуття та інших порушень з боку травного тракту, спричинених:

- вірусними або бактеріальними інфекціями травного тракту (наприклад ротавірусна інфекція, діарея мандрівників);

- застосуванням протимікробних засобів (антибіотиків або інших синтетичних протимікробних препаратів).

$L A-5^{\circ}$ та $B B-12^{\circ} €$ зареєстрованими торговими марками Chr. Hansen, Данія Лінекс Форте , капсули тверді, UA/14763/01/01 Інформація для спеціалістів сфери охорони здоров'я 4-41-ЛИН-0ТС-0321

\section{Список використаної літератури/References:}

1. McFarland L.V. (2008) Antibiotic-associated diarrhea: epidemiology, trends and treatment. Future Microbiol., 3(5): 563-578. D0l:10.2217/17460913.3.5.563

2. Andreeva I.V., Stetsyuk 0.U. (2018) The place of probiotics in practice guidelines for gastroenterology: reality and near-term prospects. Consil. Medicum, 20(8): 67-72 (In Rus.).

3. Hickson M. (2011) Probiotics in the prevention of antibiotic-associated diarrhoea and Clostridium difficile infection. Therap. Adv. Gastroenterol., 4(3): 185-197. D0I: 10.1177/1756283X11399115.

4. Tian C.F., Su B.Y., Li Y.J. et al. (2016) Management of antibiotic-associated pseudomembranous colitis in Non-hospitalized and hospitalized patients. Pak. J. Pharm. Sci., 29(5 Suppl.): 1805-1810.

5. ZhangY., Sun J., Zhang J. et al. (2018) Enzyme Inhibitor Antibiotics and Antibiotic-Associated Diarrhea in Critically III Patients. Med. Sci. Monit., 4(24): 8781-8788. D0I: 10.12659/MSM.913739.
6. Gilbert D.N. (1995) Aspects of the safety profile of oral antimicrobial agents. Infect. Dis. Clin. Pract., 3(3): 236-245.

7. Wiström J., Norrby S.R., Myhre E.B. et al. (2001) Frequency of antibiotic-associated diarrhoea in 2462 antibiotic-treated hospitalized patients: a prospectivestudy.J. Antimicrob. Chemother., 47(1): 43-50. D0I: 10.1093/jac/47.1.43.

8. BartlettJ.G. (2002)Clinical practice. Antibiotic-associated diarrhea. N. Engl.J.Med.,346(5):334-339. D0l: 10.1056/NEJMcp011603.

9. Skrypnykl.N.,MaslovaA.S.,Mandryka Ya.A. (2013) Modern spore-forming probiotics in the treatment of intestinal microbiocenosis disorders: efficacy and safety. Community health, 3-4: 73-81 (In Rus.).

10. Alam S., Mushtaq M. (2009) Antibiotic associated diarrhea in children. Indian. Pediatr., 46(6): 491-496.

11. Zvyagintseva T.D., Chernobay A.I. (2011) Antibiotic-associated diarrhea: treatment approaches. Health of Ukraine, 18: 24-25 (In Rus.).

12. Zhou H., Xu Q., Liu Y., Guo L.T. (2020) Risk factors, incidence, and morbidity associated with antibiotic-associated diarrhea in intensive care unit patients receiving antibiotic monotherapy. World J. Clin. Cases, 8(10): 1908-1915. D0l: 10.12998/wjcc.v8.i10.1908

13. Maev I.V., Samsonov A.A., Golubev N.N. (2007) Antibiotic-associated diarrhea. Gastroenterology. Consilium medicum, 1: 20-24 (In Rus.).

14. Khavkin A.I. (2018) Antibiotic-associated diarrhea: potential use of probiotics. Difficult patient, 16(1-2): 452 (In Rus.)

15. Hookman P., Barkin S.J. (2009) Clostridium difficile associated infectition, diarrhea and colitis. World J. Gastroenterol., 15(13): 1554-1580. D0l:10.3748/wjg.11554.

16. Gazzola A., Panelli S., Corbella M. et al. (2020) Microbiota in Clostridioides difficile-Associated Diarrhea:Comparison in Recurrentand Non-Recurrent Infections. Biomedicines, 8(9):E335.D01:10.3390/ biomedicines 8090335 .

17. De Roo A.C., Regenbogen S.E. (2020) Clostridium difficile Infection: An Epidemiology Update. Clinics in colon and rectal surgery, 33(2): 49-57 (https://doi.org/10.1055/s-0040-1701229).

18. Hell M., Bernhofer C., Stalzer P. et al. (2013) Probiotics in Clostridium difficile infection: reviewing the need for a multistrain probiotic. Beneficial Microbes, 4(1):39-35.D0I: 10.3920/BM2012.0049.

19. Allen S.J., Wareham K., Wang D. et al. (2013) Lactobacilli and bifidobacteria in the prevention of antibiotic-associated diarrhoea and Clostridium difficile diarrhoea in older inpatients (PLACIDE): a randomised, double-blind, placebo-controlled, multicentre trial. Lancet, 382(9900): 1249-1257. DOI: 10.1016/S0140-6736(13)61218-0.

20. Kukla M., Adrych K., Dobrowolska A. et al. (2020) Guidelines for Clostridium difficile infection in adults. Prz Gastroenterol., 15(1): 1-21. D0l: 10.5114/pg.2020.93629.

21. McDonald L.C., Gerding D.N., Johnson S. et al. (2018) Clinical Practice Guidelines for Clostridium difficile Infection in Adults and Children: 2017 Update by the Infectious Diseases Society of America (IDSA) and Society for Healthcare Epidemiology of America (SHEA). Clin. Infect. Dis., 66(7): e1-e48. DOl: 10.1093/cid/cix1085.

22. Lupse M., Flonta M., Cioara A. (2013) Predictors of first recurrence in Clostridium difficile-associated disease. Astudy of 306 patients hospitalized in a Romanian tertiary referral center. J. Gastrointestin. Liver Dis., 22(4): 397-403. D0l:10.1093/cid/cis356.

23. Hill C., Guarner F., Reid G. et al. (2014) The International Scientific Association for Probiotics and Prebiotics consensus statement on the scope and appropriate use of the term probiotic. Nat. Rev. Gastroenterol. Hepatol., 11(8): 506-514. D0l: 10.1038/nrgastro.2014.66.

24. FAO/WHO (2012) Report of a Joint FAO/WHO Working group. Guidelines for evaluation of probiotics in food. London, Ontario, Canada.

25. Glushanova N.A. (2003) Biological properties of Lactobacillus. Bulletin of Siberian Medicine, 2(4): 50-58 (In Rus.).

26. Novik I. (2006) Bifidobacterium: scientific basis for practical use. Health and environmental issues, 3(9): 144-151 (In Rus.).

27. MarkowiakP.,Śliżewska K. (2017) Effects of Probiotics, Prebiotics, and Synbiotics on Human Health. Nutrients, 9(9): 1021. D0l: 10.3390/nu9091021.

28. Collado M.C., Meriluoto J., Salminen S. (2007) Role of commercial probiotic strains against human pathogen adhesion to intestinal mucus. Lett. Appl. Microbiol., 45: 454-460. D0I: 10.1111/j.1472-765X.2007.02212.x.

29. Martins F.C., Silva A.A., Vieira A.T. et al. (2009) Comparative study of Bifidobacterium animalis, Escherichia coli, Lactobacillus casei and Saccharomyces boulardii probiotic properties. Arch. Microbial., 191(8): 623-630. D01: 10.1007/s00203-009-0491-x.

30. Andreeva I.V., Stetsyuk 0.U. (2016) Efficacy and safety of the combination of Lactobacillus acidophilus $L A-5$ and Bifidobacterium lactis BB-12 in gastroenterology, pediatrics and allergology. Clinical Microbiology and Antimicrobial Chemotherapy, 18(2): 113-124 (In Rus.).

31. Zeinhom M.,TellezA.M.,DelcenserieV. etal. (2012)Yoghurt containing bioactivemolecules produced by Lactobacillus acidophilus La-5 exerts a protective effect against enterohemorrhagic Escherichia coli (EHEC) in mice. J. Food Prot., 10: 1796-1805. D01:10.4315/0362-028X.JFP-11-508.

32. Medellin-Pena M.J., Griffiths M.W. (2009) Effect of molecules secreted by Lactobacillus acidophilus strain La-5 on Escherichia coli0157:H7 colonization. Applied and Environmental Microbiology, 75(15): 1165-1172. DOl: 10.1128/AEM.01651-08. 
33. Juntunen M., Kirjavainen P.V., Ouwehand A.C. etal. (2001) Adherence of probiotic bacteria to human intestinal mucus in healthy infants and during rotavirus infection. Clin. Diagn. Lab. Immunol., 8(2): 293-296. DOl: 10.1128/CDLI.8.2.293-296.2001.

34. Ouwehand A.C.,Salminen S., Tölkkö S. et al. (2002) Resected human colonic tissue: new model for characterizing adhesion of lacticacid bacteria. Clin. Diagn.Lab.Immunol.,9:184-186.D0l:10.1128/ cdli.9.1.184-186.2002

35. Kekkonen R. (2008) Immunomodulatory Effects of Probiotic Bacteria In Healthy Adults. Academic Dissertation. Helsinki, $122 \mathrm{p}$.

36. Jungersen M., Wind A., Johansen E. et al. (2014) The science behind the probiotic strain Bifidobacterium animalis subsp. Lactis BB-12R. Microorganisms, 2: 92-110. D0l:10.3390/microorganisms2020092.

37. Zhang D.Y.,PanZ.Y.,Yu X.K. etal. (2019) Bifidobacterium lactis BB-12 Attenuates Macrophage Aging Induced by D-Galactose and Promotes M, Macrophage Polarization.J.Immunol. Res., 2019: 4657928. DOl: 10.1155/2019/4657928

38. Singer M.Ya., Pidgorsky V.S., Lazarenko L.M. et al. (2009) Influence of lacto- and bifidobacteria on the indicators of immunoreactivity of the organism in the experimental model. Microbiology and biotechnology, 1(5): 39-48 (In Ukr.).

39. Anitha M., Vijay-Kumar M., Sitaraman S.V. et al. (2012) Gut microbial products regulate murine gastrointestinal motility via Toll-like receptor 4 signaling. Gastroenterology, 143(4): 1006-1016. DOl: 10.1053/j.gastro.2012.06.034.

40. Eskesen D., Jespersen L., Michelsen B. et al. (2015) Effect of the probiotic strain Bifidobacterium animalis subsp. lactis, $B B-12^{\circledR}$, on defecation frequency in healthy subjects with low defecation frequency and abdominal discomfort: a randomised, double-blind, placebo-controlled, parallelgroup trial. Br. J. Nutr., 114: 1638-1646.

41. Li S.-Ch., Hsu W.-F., Chang J.-S., Shih Ch.-K. (2019) Combination of Lactobacillus acidophilus and Bifidobacterium animalis subsp. lactis Shows a Stronger Anti-Inflammatory Effect than Individual Strains in HT-29 Cells. Nutrients, 11(5): 969. doi: 10.3390/nu11050969.

42. GongY., LiY., Sun Q. (2015) Probiotics improve efficacy and tolerability of triple therapy to eradicate Helicobacter pylori: a meta-analysis of randomized controlled trials. Int. j. Clin. Exp. Med., 8(4): 6530-6543.

43. Blaabjerg S., Artzi D.M., Aabenhus R. (2017) Probiotics for the Prevention of Antibiotic-Associated Diarrhea in Outpatients — A Systematic Review and Meta-Analysis. Antibiotics (Basel), 6(4): 21. D01: $10.3390 /$ antibiotics6040021.

44. Guo Q., Goldenberg J.Z., Humphrey C. et al. (2019) Probiotics for the prevention of pediatric antibiotic-associated diarrhea. Cochrane Database Syst. Rev., 4(4): CD004827. D0I: 10.1002/14651858. CD004827.pub5

45. Videlock E.J., Cremonini F. (2012) Meta-analysis: probiotics in antibiotic-associated diarrhoea. Aliment. Pharmacol. Ther., 35(12): 1355-1369. D0l: 10.1111/j.1365-2036.2012.05104.x.

46. Lü M., Yu S., Deng J. et al. (2016) Efficacy of Probiotic Supplementation Therapy for Helicobacter pylori Eradication: A Meta-Analysis of Randomized Controlled Trials. PLoS One, 11(10): e0163743. D01: 10.1371/journal.pone.0163743.

47. De Vrese M., Kristen H., Rautenberg P. et al. (2011) Probiotic lactobacilli and bifidobacteria in a fermented milk product with added fruit preparation reduce antibiotic associated diarrhea and Helicobacter pylori activity. J. Dairy Res., 78(4): 396-403. D0I: 10.1017/ S002202991100063X.

48. Fang H.R., Zhang G.Q., Cheng J.Y. etal. (2019) Efficacy of Lactobacillus-supplemented triple therapy for Helicobacter pylori infection in children: a meta-analysis of randomized controlled trials. Eur. J. Pediatr., 178(1): 7-16. D0l: 10.1007/s00431-018-3282-z.

49. Guarner F., Sanders M.E., Eliakim R. et al. (2017) Probiotics and prebiotics: WGO Global Guidelines. $36 \mathrm{p}$.

50. Plotnikova E.Yu., Zakharova Yu.V., Gracheva T.Yu. (2017) Possibilities of using Linex Forte ${ }^{\circledR}$ in clinical practice. Med. advice, 5: 94-98 (In Rus.).

51. Chatterjee S., Kar P., Das T. et al. (2013) Randomised placebo-controlled double blind multicentric trial on efficacy and safety of Lactobacillus acidophilus $L A-5$ and Bifidobacterium BB-12 for prevention of antibiotic-associated diarrhoea. J. Assoc. Physicians India, 61(10): 708-712.

\section{Відомості про авторів:}

Скрипник Ігор Миколайович — доктор медичних наук, професор, проректор з науково-педагогічної роботи та післядипломної освіти, професор кафедри внутрішньої медицини № 1 Української медичної стоматологічної академії, Полтава, Україна. ORCID ID: 0000-0002-3426-3429 Приходько Наталія Петрівна — кандидат медичних наук, асистент кафедри внутрішньої медицини № 1 Української медичної стоматологічної академії, Полтава, Україна. ORCID ID: 00000001-5552-2656

\section{Адреса для кореспонденції:}

Скрипник Ігор Миколайович

36011, Полтава, вул. Шевченка, 23

E-mail:inskrypnyk@gmail.com
52. Fox M.J., Ahuja K.D., Robertson I.K. et al. (2015) Can probiotic yogurt prevent diarrhoea in children on antibiotics? A double-blind, randomised, placebo-controlled study. BMJ Open, 5(1): e006474. DOl: 10.1136/bmjopen-2014-0074.

53. Martin C.R., Osadchiy V., Kalani A., Mayer E.A. (2018) The Brain-Gut-Microbiome Axis. Cell Mol. Gastroenterol. Hepatol., 6(2): 133-148. D0l: 10.1016/j.jamgh.2018.04.003.

54. Carabotti M., Scirocco A., Maselli M.A., Severi C. (2015) The gut-brain axis: Interactions between enteric microbiota, central and enteric nervous systems. Ann. Gastroenterol., 28(2): 203-209.

55. ChunchaiT.,ThunapongW.,Yasom S. etal. (2018) Decreased microglial activation through gut-brain axis by prebiotics, probiotics, or synbiotics effectively restored cognitive function in obese-insulin resistant rats. J. Neuroinflammation, 15(1): 11. D0l: 10.1186/s12974-018-1055-2.

56. Yang C., Fujita Y., Ren Q. et al. (2017) Bifidobacterium in the gut microbiota confer resilience to chronic social defeat stress in mice. Sci. Rep., 7: 45942. D0l: 10.1038/srep45942.

57. Wang L., Guo M. J., Gao Q. et al. (2018) The effects of probiotics on total cholesterol: a meta-analysis of randomized controlled trials. Medicine (Baltimore), 97(5): e9679. D0l:10.1097/ MD.0000000000009679.

58. Mo R., ZhangX., Yang, Y. (2019) Effect of probiotics on lipid profiles in hypercholesterolaemic adults: a meta-analysis of randomized controlled trials. Medicina Clínica, 152(12):473-481.D0l: 10.1016/j. meddi.2018.09.007.

59. Klaver F.A., van der Meer R. (1993) The assumed assimilation of cholesterol by Lactobacilli and Bifidobacterium bifidum is due to their bile salt-deconjugating activity. Appl. Environ. Microbiol., 59 : $1120-1124$

60. Pereira D.I., Gibson G.R. (2002) Effects of consumption of probiotics and prebiotics on serum lipid levels in humans. Crit. Rev. Biochem. Mol. Biol., 37: 259-281. D0I: 10.1080/10409230290771519.

61. Ejtahed H.S., Mohtadi-Nia J., Homayouni-Rad A. et al. (2011) Effect of probiotic yogurt containing Lactobacillus acidophilus and Bifidobacterium lactis on lipid profile in individuals with type 2 diabetes mellitus. J. Dairy Sci., 94(7): 3288-3294. https://doi.org/10.3168/jds.2010-4128.

62. Tonucci L.B., Olbrich Dos Santos K.M., de Oliveira L.L. (2017) Clinical application of probiotics in type 2 diabetes mellitus: a randomized, double-blind, placebo-controlled study. Clin. Nutr., 36(1):85-92. https://doi.org/10.1016/j.lnu.2015.11.011

63. Kocsis T., Molnár B., Németh D. et al. (2020) Probiotics have beneficial metabolic effects in patients with type 2 diabetes mellitus: a meta-analysis of randomized clinical trials. Sci. Rep., 10(1):11787. https://doi.org/10.1038/s41598-020-68440-1.

\section{Antibiotic-associated diarrhea: the role of probiotics in the treatment and prevention}

\section{I.M. Skrypnyk, N.P. Prykhodko}

Ukrainian Medical Stomatological Academy, Poltava, Ukraine

Abstract. Antibacterial drugs, like any drug, have certain side effects, in particular, one of them is diarrhea caused by their use. The main reasons for the development of antibiotic-associated diarrhea, forms of the disease, features of diagnosis and etiotropic treatment are considered in the article. Based on the publications of domestic and foreign researchers, data of probiotics prescription for the prevention and treatment of antibiotic-associated diarrhea are presented. Possibilities of using probiotics, in particular Bifidobacterium lactis $B B-12^{\circledR}$ and Lactobacillus acidophilus $L A-5^{\circledR}$, for prevention of complications of antihelicobacter infection, their influence on glycemic control and lipid profile of patients are described.

Key words: antibiotic-associated diarrhea, probiotics, Bifidobacterium lactis $B B-12^{\circledR}$, Lactobacillus acidophilus $L A-5^{\circledR}$

\section{Information about the authors:}

Skrypnyk Ihor M. - Honored Master of Science and Technology of Ukraine, Doctor of Medical Sciences, Professor, Vice-Rector for Academic Affairs and Postgraduate Education, Department of Internal Medicine № 1 of the Ukrainian Medical Stomatological Academy, Poltava, Ukraine. ORCID ID: 0000-0002-3426-3429 Prykhodko Nataliia P. - PhD in Medical Sciences, Associate Lecturer, Master of Medicine in Internal Medicine, Department of Internal Medicine № 1 of the Ukrainian Medical Stomatological Academy, Poltava, Ukraine. ORCID ID: 0000-0001-5552-2656

Address for correspondence:

Ihor Skrypnyk

36011, Poltava, Shevchenko Str., 23

E-mail:inskrypnyk@gmail.com 